\title{
Seven new species of Lachesilla (Psocodea: 'Psocoptera': Lachesillidae), in the group forcepeta from the Amazon Basin
}

\author{
Alfonso N. García ALDRETE ${ }^{1}$
}

\section{ABSTRACT}

Seven new species of Lachesilla in the group forcepeta, from the Amazon Basin in Brazil, Colombia and Peru, are here described and illustrated: L. amacayacuensis sp. n. (type locality: Colombia, Amazonas, Leticia, Amacayacú); L.bulbosiforceps sp. n. (type locality: Peru, Cuzco); L. cuzcoensis sp. n. (type locality: Peru, Cuzco); L. marabaensis sp. n. (type locality: Brasil, Pará, Marabá, Serra Norte); L. pilosiforceps sp. n. (type locality: Brasil, Pará, Oriximiná, Rio Trombetas); L. pilosipenna sp. n. (type locality: Peru, Cuzco); L. squamiforceps sp. n. (type locality: Colombia, Amazonas, Leticia). The Amazon Basin is the second most rich world area for species of Lachesilla.

KEY WORDS: Brazil, Colombia, neotropics, Peru, taxonomy.

\section{Sete espécies novas de Lachesilla Westwood (Psocodea:'Psocoptera': Lachesillidae) do grupo forcepeta da Bacia Amazônica}

\section{RESUMO}

São descritas e ilustradas sete espécies de Lachesilla do grupo forcepeta, provenientes da bacia amazônica do Brasil, Colômbia e Peru: L. amacayacuensis sp. n. (localidade-tipo: Colômbia, Amazonas, Leticia, Amacayacú); L. bulbosiforceps sp. n. (localidadetipo: Peru, Cuzco); L. cuzcoensis sp. n. (localidade-tipo: Peru, Cuzco); L. marabaensis sp. n. (localidade-tipo: Brasil, Pará, Marabá, Serra Norte); L. pilosiforceps sp. n. (localidade-tipo: Brasil, Pará, Oriximiná, Rio Trombetas); L. pilosipenna sp. n. (localidade-tipo: Peru, Cuzco); L. squamiforceps sp. n. (localidade-tipo: Colômbia, Amazonas, Letícia). A regiāo amazônica é a segunda mais rica em número de espécies de Lachesilla.

PALAVRAS CHAVE: Brasil, Colômbia, regiāo Neotropical, Peru, taxonomia.

\footnotetext{
${ }_{1}$ Departamento de Zoología, Instituto de Biología, Universidad Nacional Autónoma de México, Apartado Postal 70-153, 04510 México, D. F. MÉXICO. E-mail: anga@ibiologia.unam.mx
} 


\section{INTRODUCTION}

Lachesilla is one of the most speciose and morphologically diverse genera of the order Psocoptera, with 283 species described throughout the world, and about 100 more waiting description, assigned phenetically in 17 species groups; the largest of these is forcepeta, with 86 described species, distributed in U.S.A.-Canada (12 species), Mexico (22 species), Central America (19 species), Caribbean (16 species), South America (44 species), and Africa (five species). For a diagnosis of the group see Mockford (1993) and García Aldrete (2008). The purpose of this work is to describe seven additional species of Lachesilla in the group forcepeta, found within the Amazon Basin.

\section{MATERIAL AND METHODS}

Twelve specimens were available for study, ten of which were dissected in $80 \%$ ethyl alcohol, and their parts (head, wings and legs, and genitalia) were mounted on slides in Canada Balsam. Standard measurements, given in $\mu \mathrm{m}$, were taken with a filar micrometer, whose measuring unit is $136 \mu \mathrm{m}$ for wings, and $53 \mu \mathrm{m}$ for other parts (see García Aldrete 2008). Color was recorded by placing whole specimens, before dissection, in $80 \%$ ethyl alcohol, illuminated with white cold light at 80X. The location of the types, indicated in each description, is as follows: CNIN (Colección Nacional de Insectos, Instituto de Biología, Universidad Nacional Autónoma de México, México, D. F.), ICN (Instituto de Ciencias Naturales, Universidad Nacional de Colombia, Bogotá, Colombia), INPA (Instituto Nacional de Pesquisas da Amazônia, Manaus, Amazonas, Brasil).

\section{RESULTS}

\section{Lachesilla amacayacuensis sp. $\mathrm{n}$. $\precsim$}

(Figs. 1-4)

Differential diagnosis. Distal halves of claspers slender, blunt ended, bearing distally on outer edge a field of thin, elongate scales. Differing from L. squamiforceps sp. n. (described below), the other species in the group with a distal field of scales in the claspers in that, in the latter, the distal halves of the claspers are stout, pointed, the hypandrium is deeper, more angular, and the forewing veins Rs- $\mathrm{M}$ are joined by a short crossvein (compare figures 3 and 28, and 1 and 26 in this paper).

Color. Body pale brown. Compound eyes black, ocelli hyaline, with ochre centripetal crescents. Mx3-Mx4 more pigmented than the basal palpomeres. Tergal lobes of mesoand metathorax dark brown. Wings hyaline, veins brown. Abdomen whitish, with dark brown subcuticular rings, less pigmented ventrally.

Morphology. Forewing pterostigma long, almost rectangular, wider posteriorly; veins Rs-M fused for a very short distance, areola postica broadly triangular, apically rounded; hindwing Rs-M fused for a distance (Fig. 1). Hypandrium almost trapeziform, with postero-lateral corners rounded and setae as illustrated (Fig. 3). Claspers (Fig. 3), basally narrow, widening towards distal end of proximal half, with a field of 17-19 setae, two posterior ones longer than the others; distal half slender, curved outwards, with an apical field of slender scales on inner edge. Phallosome apodeme long, stout (Fig. 3) ending distally in two broad, triangular, membranous lamellae. Paraprocts broad (Fig. 4), with setae and pigmented area as illustrated and circular sensory fields with 17-18 trichobothria on basal rosettes and a marginal trichobothrium without basal rosette. Epiproct (Fig. 2), wide, narrow, slightly concave anteriorly and rounded posteriorly, bearing a field of setae on distal half. Clunium slightly projected over the area of the epiproct.

Measurements (of holotype $\hat{\sigma}$, those of paratype $\hat{\sigma}$ in parenthesis). FW: 2293 (2292), HW: 1713 (1916), F: 490 (487), T: 894 (894), t1: 310 (310), t2: 95 (95), Mx4: 101, f1:279, f2: 267, f3: 224, f4: 180, IO: 360, D: 209, d: 148, IO/D: 1.72 , PO: 0.70 .

Type material. Colombia. Amazonas. Leticia. Amacayacú. 340.3'S: $70^{\circ} 12^{\prime} \mathrm{W}$. VIII.1988, Tierra firme, holotype ${ }^{\lambda}$. M. Kelsey. Same locality and collector, VII.1988, paratype $\widehat{\jmath}$, mutilated, without head and prothorax (ICN).

Etymology. The specific name is a toponym that refers to the type locality: Amacayacú.
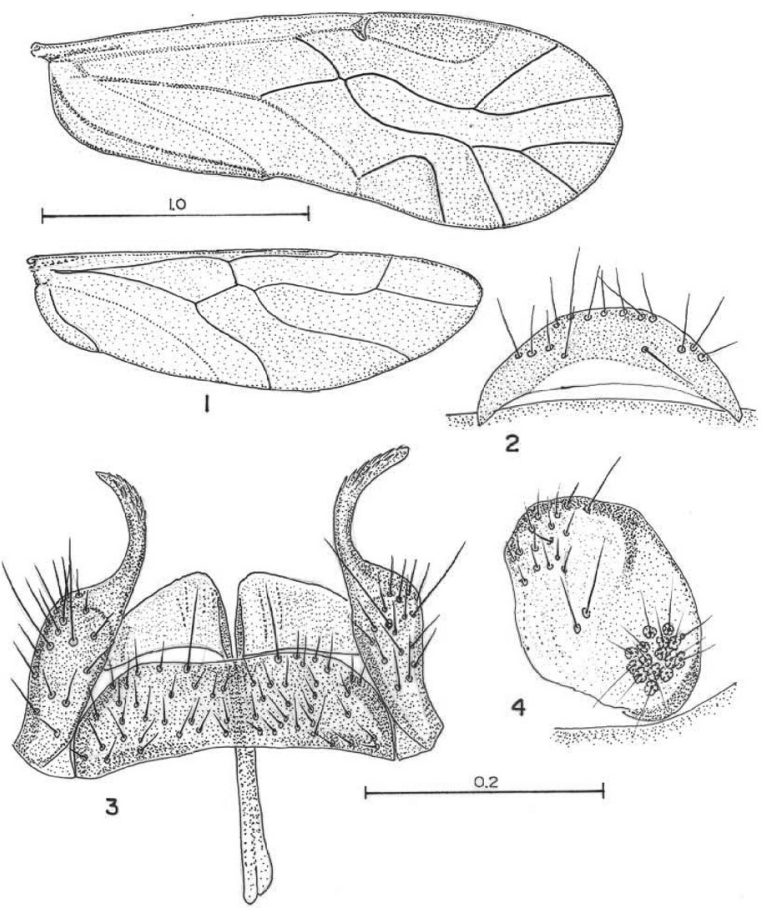

Figures 1-4 - Lachesilla amacayacuensis sp. n., male. 1. Fore- and hindwings. 2. Epiproct. 3. Hypandrium, claspers and phallosome apodeme. 4. Right paraproct. Scales in mm. Figures 2-4 to common scale. 


\section{Lachesilla bulbosiforceps sp. $\mathbf{n} . \AA$}

(Figures 5-8)

Differential diagnosis. Distal halves of claspers anteapically widened, each clasper ending in a short, truncate, sclerotized cylinder. Forewing veins, including $\mathrm{Cu} 2$, bearing a row of distinct setae; surface of pterostigma also with setae. Differing from L. pilosipenna sp. n. (described below), in that, in the latter, the distal halves of the claspers are elongate, slender, distally dilated, and the hypandrium is narrower than in L. bulbosiforceps (compare figures 7 and 23 in this paper).

Color. Body reddish brown. Compound eyes black, ocelli hyaline, with ochre centripetal crescents. Tergal lobes of meso- and metathorax dark brown; episterna of mesoand metathorax ochre, distinctly more pigmented than epimera. Wings hyaline, veins brown, vein $\mathrm{R} 1$, bordering the pterostigma strongly pigmented. Abdomen whitish, with ochre subcuticular rings, less pigmented ventrally.

Morphology. Compound eyes large, protruding laterally. Forewing with small setae on pterostigma and veins; veins Rs-M joined by a short crossvein, areola postica wide, rounded apically; hindwing veins Rs-M fused for a distance (Fig. 5). Hypandrium broad, almost trapeziform, with postero-lateral corners rounded and setose as illustrated (Fig. 7); claspers stout proximally, with a field of 20-25 setae, two posterior ones larger than the others; distal part short, swollen distally, ending in a short, strongly sclerotized truncate projection

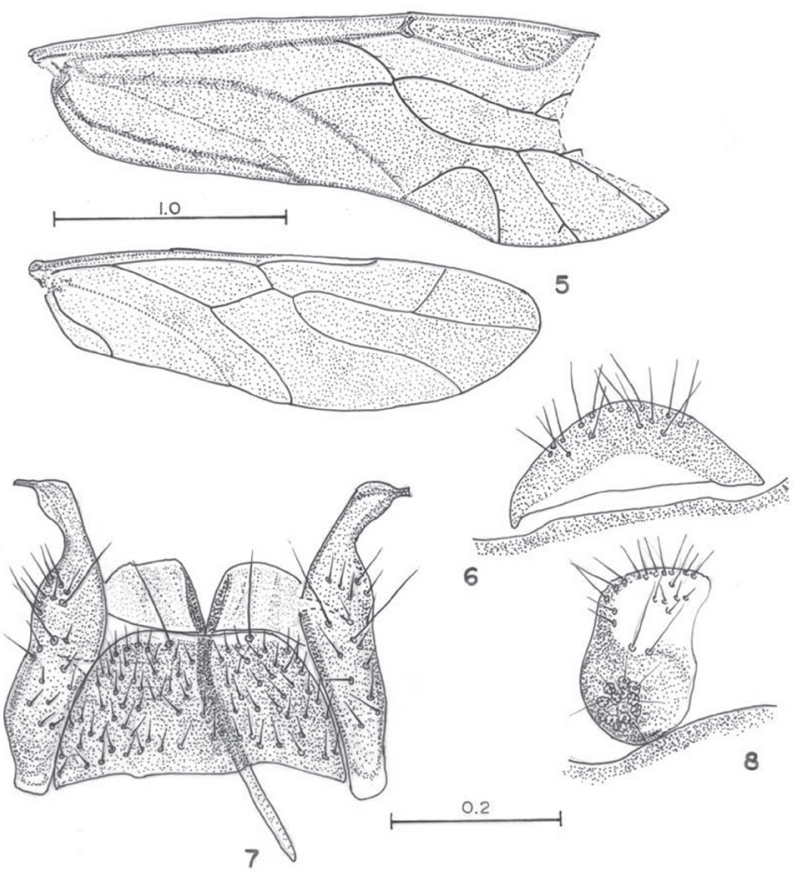

Figures 5-8 - Lachesilla bulbosiforceps sp. n., male. 5. Fore- and hind- wings. 6. Epiproct. 7. Hypandrium, claspers and phallosome apodeme. 8. Left paraproct. Scales in mm. Figures 6-8 to common scale.
(Fig. 7); phallosome apodeme long, slender, ending distally in two broad membranous lamellae (Fig. 7). Paraprocts (Fig. 8), broad, setose and pigmented as illustrated, with sensory fields circular, bearing 13-14 trichobothria on basal rosettes, and a marginal trichobothrium without basal rosette. Epiproct (Fig. 6), wide, almost straight anteriorly, rounded posteriorly, with a field of setae on distal half. Clunium slightly projected over the area of the epiproct.

Measurements. FW: 2938, HW: 2268, F: 782, T: 1341, t1: 516, t2: 130, ctt1: 34, Mx4: 113, f1: 481, f2: 474, f3: 444, f4: 328, f5: 186, f6: 168, f7: 149, IO: 407, D: 247: d: 223 , IO/D: 1.64, PO: 0.90 .

Type material. Peru. Cuzco. Lower Urubamba Region.

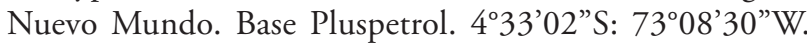
VII.2004. Light trap, J. Williams, holotype ${ }^{\lambda}$, two paratypes $\hat{\sigma}$ (CNIN).

Etymology. The specific name, a noun in apposition, refers to the distal swelling of the male claspers.

\section{Lachesilla cuzcoensis sp. $\mathbf{n}$. +}

(Figures 9- 12)

Differential diagnosis. Wings wide, short. Forewing areola postica rounded, almost straight posteriorly. Subgenital plate straight posteriorly. Pigmented area of epiproct widely concave anteriorly. Differing from its sister species $L$. ruizabreorum García Aldrete (2004), in that, in the latter the forewing areola postica is triangular, the subgenital plate is decidedly concave posteriorly, the pigmented area of the epiproct is very narrowly concave anteriorly, and the clunium is projected posteriorly over the area of the epiproct (compare figures 9-11 in this paper, with figures 33-35 in García Aldrete 2004).

Color. Body brown. Compound eyes black, ocelli hyaline, with ochre centripetal crescents. Wings reddish brown, veins brown, vein R1 bordering pterostigma, ochre. Abdomen whitish, with dark brown subcuticular rings, less pigmented ventrally.

Morphology. Forewing pterostigma short, almost rectangular, wider posteriorly, veins Rs-M diverging from a point, areola postica medium-small, tall, rounded apically; hindwing veins Rs-M fused for a distance (Fig. 9). Subgenital plate (Fig. 11) broad, almost straight posteriorly, uniformly pigmented, setae as illustrated. Gonapophyses (Fig. 12) large, broad, with inner edge straight and outer edge curved, blunt ended, setose. Spermapore (Fig. 12) large, in center of ninth sternum, surrounded by large, triangular pigmented area. Paraprocts (Fig. 10) semi-elliptic, unpigmented posteriorly, with setae as illustrated; sensory fields circular, with 11 trichobothria on basal rosettes and a marginal trichobothrium without basal rosette. Epiproct broadly triangular (Fig. 10), with a field of setae on distal half. 
Measurements. FW: 1666, HW: 1281, F: 343, T: 669, t1: 213, t2: 82, ctt1: 17, f1: 186, f2: 162, f3: 132, f4: 100, f5: 61, IO: 291, D: 165, d: 94, IO/D: 1.76, PO: 0.56.

Type material. Peru. Cuzco. Lower Urubamba Region.

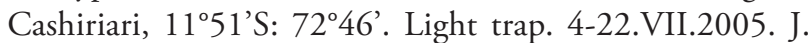
Williams. Holotype 9 (CNIN).

Etymology. The specific name is a toponym that refers to Cuzco, where the holotype was collected.

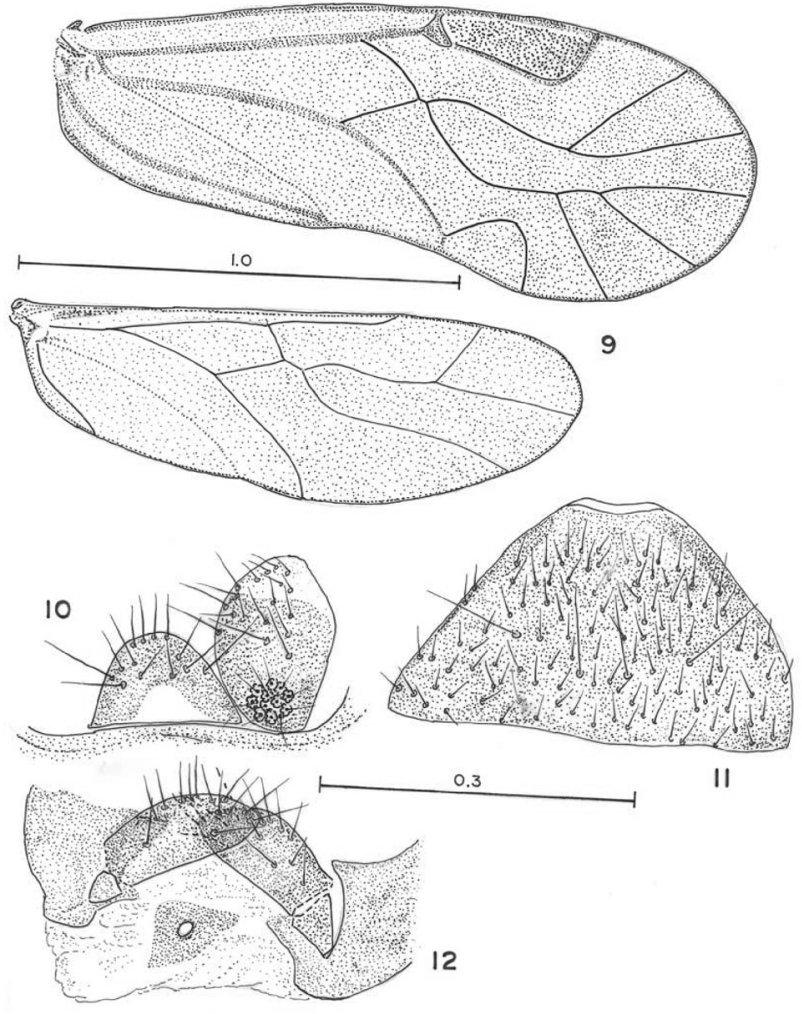

Figures 9 -12 - Lachesilla cuzcoensis sp. n., female. 9. Fore- and hindwings. 10. Epiproct and left paraproct. 11. Subgenital plate. 12. Extremes of clunium, gonapophyses and ninth sternum. Scales in mm. Figures 10-12 to common scale.

\section{Lachesilla marabaensis sp. $\mathbf{n} . \widehat{\sigma}$}

(Figures 13-16)

Differential diagnosis. Hypandrium projected posteriorly in the middle to form a small cone. Distal halves of claspers stout, distally pointed, with a small protuberance on outer edge, in the middle, and at the same level, with a distinct jagged projection on inner edge. Epiproct almost trapeziform, with antero-lateral corners slightly projected, and with a transverse, sclerotized band next to posterior border. Such a combination of characters is unique among the other species of the group (see Discussion below).
Color. Body pale brown. Compound eyes black, ocelli hyaline, without pigmented centripetal crescents. Tergal lobes of meso- and metathorax more pigmented than rest of the thorax. Wings hyaline, veins yellowish brown. Abdomen whitish, with pale brown subcuticular rings, less pigmented ventrally.

Morphology. Forewing pterostigma long, almost rectangular, wider posteriorly; veins Rs-M fused for a short distance, areola postica wider than tall, apically rounded; hindwing veins Rs-M fused for a distance (Fig. 13). Hypandrium (Fig. 15) wide, broad, slightly concave anteriorly and projected posteriorly in the middle to form a short, distally blunt cone. Claspers robust, proximally elliptic, bearing two large setae; distal portion stout, curved, wider in the middle, terminally acuminate, with a broad, distally jagged projection in the middle of inner edge; phallosome apodeme short, slender, widening distally to end in a single, broadly triangular membranous area (Fig. 15). Paraprocts (Fig. 14), broad, elliptic, with setae and pigmented area as illustrated, with sensory fields circular, bearing 11 trichobothria on basal rosettes and a marginal trichobothrium without basal rosette. Epiproct (Fig. 16) broad, almost trapeziform, with the antero-lateral corners projected, and a transverse, sclerotized band near posterior border; a field of setae on each postero-lateral corner, a group of setae in the middle, anterior to the sclerotized band, and

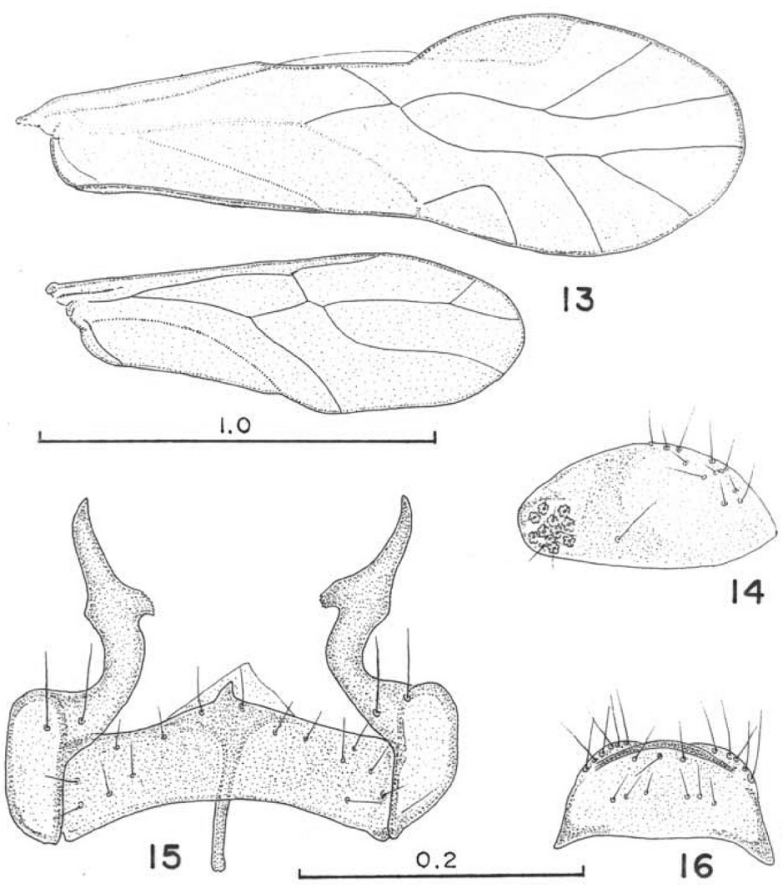

Figures 13 - 16 - Lachesilla marabaensis sp. n., male. 13. Fore- and hindwings. 14. Left paraproct. 15. Hypandrium, claspers and phallosome apodeme. 16. Epiproct. Scales in mm. Figures 14-16 to common scale. 
a transverse line of setae mesally. Clunium slightly projected posteriorly over the area of the epiproct, with the border strongly sclerotized.

Measurements. FW: 1768, HW: 1232, F: 367, T: 725, t1: 255, t2: 82, ctt1: 21, Mx4: 84, IO. 217, D: 204, d: 149, IO/D: 1.06, PO: 0.72 .

Type material. Brazil. Pará. Marabá. Serra Norte. XI.1982. Light trap. M. Miles. Holotype ô (INPA).

Etymology. The specific name is the toponym of Marabá, the type locality of this species.

\section{Lachesilla pilosiforceps sp. $\mathbf{n}$. $\overbrace{}^{\lambda}$}

(Figures 17-20)

Differential diagnosis. Distal halves of claspers slender, slightly dilated distally, bearing a field of small spines on inner edge. This species is close to L. spiniforceps García Aldrete, from Tambopata, Peru, also in the Amazon basin, the latter has a field of medium long spines ante-apically on each clasper.

Color. Body pale brown, compound eyes black, ocelli hyaline, with ochre centripetal crescents. Mx3 and Mx4 dark brown, more pigmented than basal palpomeres. Tergal lobes of meso- and metathorax dark brown. Wings hyaline, veins pale brown. Abdomen with dark brown subcuticular rings, less pigmented ventrally.

Morphology. Forewing pterostigma almost rectangular, wider posteriorly; veins Rs-M diverging from a point, areola postica wide, tall, apically rounded; hindwing veins

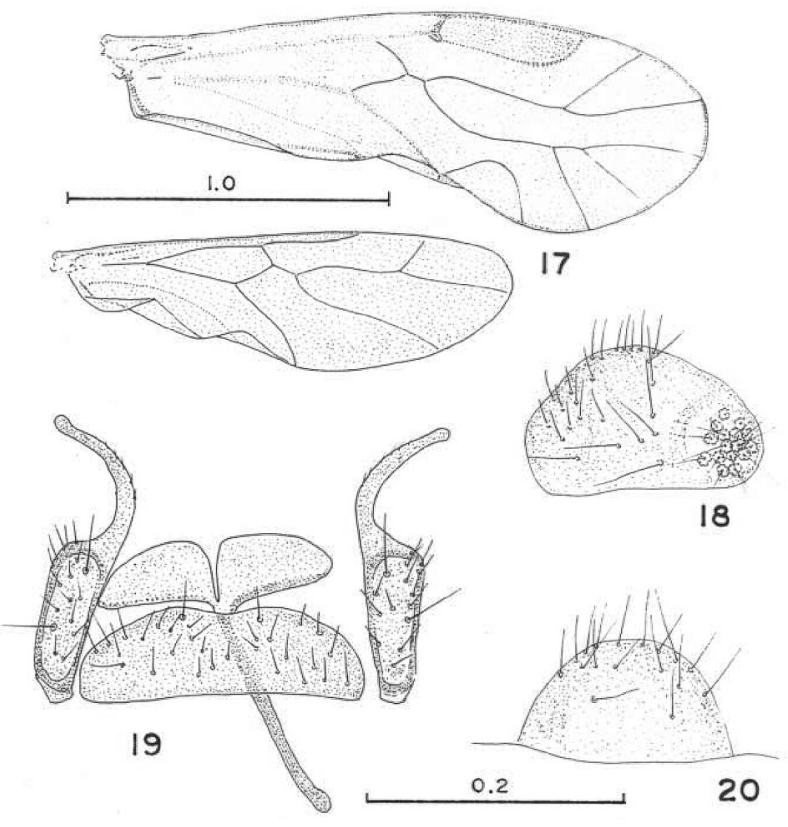

Figures 17-20 - Lachesilla pilosiforceps sp. n., male. 17. Fore- and hindwings. 18. Right paraproct. 19. Hypandrium, claspers and phallosome apodeme. 20. Epiproct. Scales in mm. Figures 18-20 to common scale.
Rs-M fused for a distance (Fig. 17). Hypandrium (Fig. 19) trapeziform, slightly concave posteriorly, with postero-lateral corners rounded, and setae as illustrated. Proximal half of claspers (Fig. 19), narrow at base and widening posteriorly, with a field of 18-20 setae, two of them much longer than the others; distal half of claspers curved outwards, with apex dilated and a field of fine setae along outer surface; phallosome apodeme long, slender, distally divided to form two broad, wide, almost triangular lamellae (Fig. 19). Paraprocts robust (Fig. 18), setose and pigmented as illustrated, with sensory fields circular, bearing 12-13 trichobothria issuing from basal rosettes and a marginal trichobothrium without basal rosette. Epiproct almost semicircular (Fig. 20), with field of setae on distal half. Clunium slightly projected posteriorly over the area of the epiproct.

Measurements. FW: 1876, HW: 1426, Mx4: 94, IO: 286, D: 189 , d: 134, IO/D: 1.51, PO: 0.70.

Type locality. Brazil. Pará. Oriximiná. Río Trombetas. ALCOA mines. 5-16.X.1982. Malaise trap. J. A. Rafael. Holotype $\hat{\sigma}$ (INPA).

Etymology. The specific name, a noun in apposition, refers to the setae on the claspers of this species.

\section{Lachesilla pilosipenna n. sp. $\widehat{\sigma}$}

(Figures 21-25)

Differential diagnosis. Wings slender, elongate; forewing with distinct setae on all veins and pterostigma. Distal halves of claspers elongate, curved, distally dilated. See also differential diagnosis of $L$. bulbosiforceps sp. n., for differences between these two species.

Color. Body pale brown. Compound eyes black, ocelli hyaline, with reddish brown centripetal crescents. Tergal lobes of meso- and metathorax dark brown, pleura with dark brown spots above the coxae. Wings hyaline, veins brown. Abdomen whitish, with dark brown subcuticular rings, less pigmented ventrally.

Morphology. Compound eyes large, protruding laterally (Fig. 25). Wings long, slender, forewing with small setae on veins, pterostigma elongate, almost rectangular, wider posteriorly, veins Rs-M diverging from a point, areola postica almost twice as wide as tall, rounded apically; hindwing veins Rs-M fused for a distance (Fig. 21). Hypandrium (Fig. 23) wide, setose, almost trapeziform, concave posteriorly and extended anteriorly as illustrated. Claspers with proximal half robust, with sides parallel, bearing a setal field of 1820 setae, two posterior much longer than the others; distal half stout, curved outwards, with apex distinctly dilated (Fig. 23). Phallosome apodeme stout, distally ending in two large, triangular, membranous lamellae (Fig. 23). Paraprocts broad, with setae and pigmented area as illustrated; sensory fields circular, with 13 trichobothria on basal rosettes and 
a marginal trichobothrium without basal rosette (Fig. 24). Epiproct (Fig. 22), almost semicircular, with pigmented area as illustrated and setal field on distal half. Clunium slightly projected posteriorly over the area of the epiproct.

Measurements. FW: 2857, HW: 2152, F: 906, T: 1343, t1: 506, t2: 141, ctt1: 23, IO: 401, D: 230, d: 192, IO/D: 1.74, PO: 0.86 .

Type material. Peru. Cuzco. Lower Urubamba Region. Nuevo Mundo, Base Pluspetrol. 4³3’02”S: 7308'30”W. VII.2004. Light trap. J. Williams. Holotype $\widehat{\partial}$ (CNIN).

Etymology. The specific name, a noun in apposition, refers to the setae on the forewing veins.

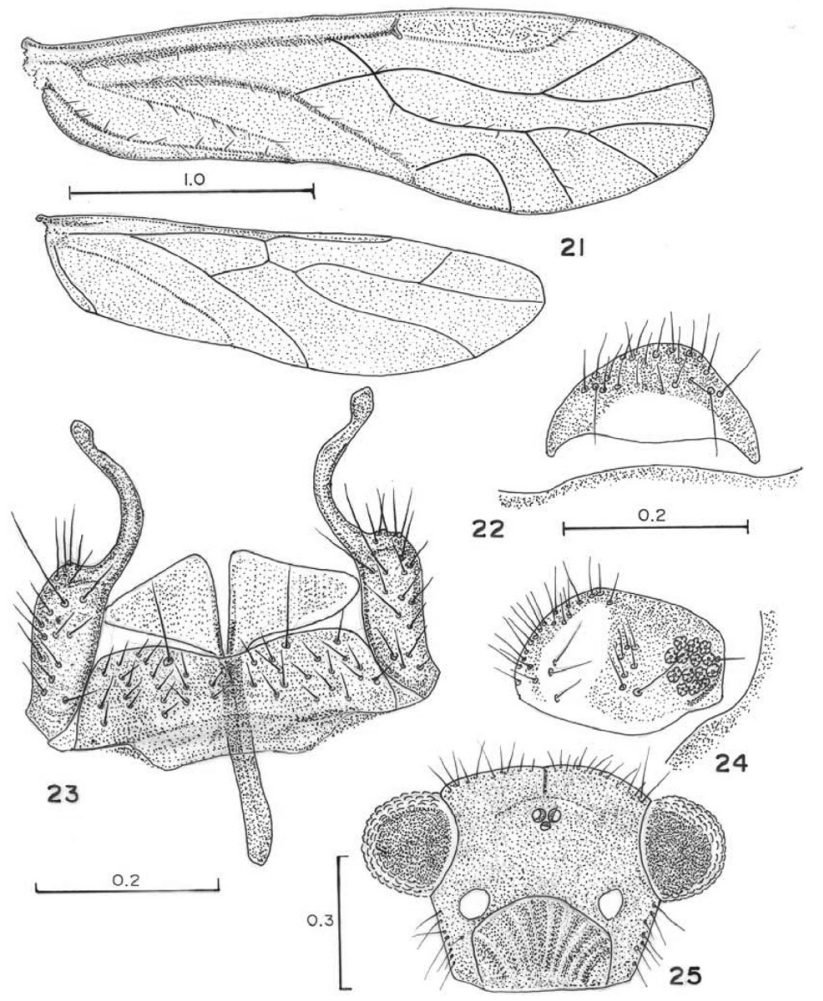

Figures 21-25 - Lachesilla pilosipenna sp. n., male. 21. Fore- and hind- wings. 22. Epiproct. 23. Hypandrium, claspers and phallosome apodeme. 24. Right paraproct. 25. Front view of head, proximal end omitted. Scales in $\mathrm{mm}$. Figure 24 to scale of figure 22.

\section{Lachesilla squamiforceps $\mathrm{n}$. sp. $\partial$}

(Figures 26-29)

Differential diagnosis. Distal halves of claspers quite stout, curved outwards, distally pointed, bearing distally a field of slender scales. Hypandrium trapeziform, straight posteriorly, wide antero-posteriorly, transverselly narrow.
See also differential diagnosis of $L$. amacayacuensis sp. n., for differences between these two species.

Color. Body pale brown. Compound eyes black, ocelli hyaline, with ochre centripetal crescents. Mx3 and Mx4 more pigmented than the basal palpomeres. Tergal lobes of mesoand metathorax dark brown. Wings hyaline, veins brown. Abdomen whitish, with dark brown subcuticular rings, less pigmented ventrally.

Morphology. Forewing pterostigma almost rectangular, wider posteriorly, veins Rs-M diverging from a point; areola postica almost twice as wide as tall, apically rounded; hindwing veins Rs-M fused for a distance (Fig. 26). Hypandrium narrow (Fig. 28), long, almost trapeziform, setose as illustrated, with anterior border concave, projected in the middle; claspers robust, proximal half broad, with a field of 12-14 setae, two posterior longer than the others; distal half robust, curved outwards, distally with a compact field of elongate, slender scales; paraprocts broad, setose and pigmented as illustrated, sensory fields circular, with 13 trichobothria on basal rosettes and a marginal trichobothrium without basal rosette (Fig. 29). Epiproct (Fig. 27), concave anteriorly, rounded posteriorly, pigmented as illustrated and with a setal field on distal half. Clunium slightly projected posteriorly over the area of the epiproct.
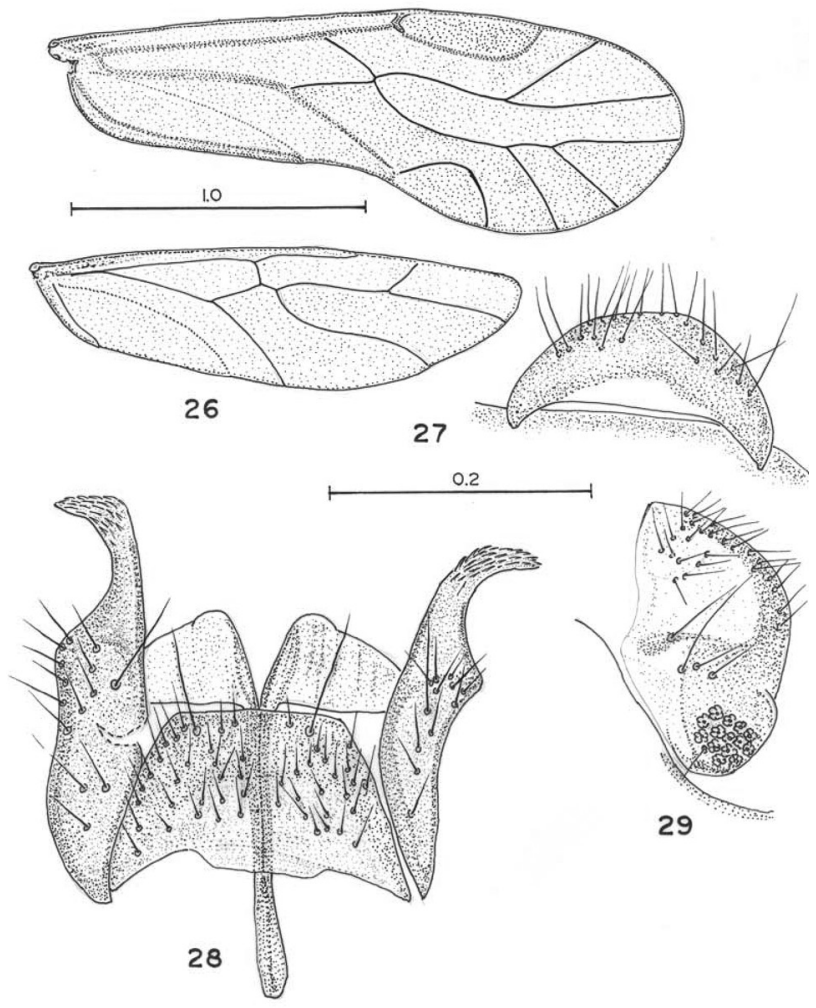

Figures 26-29 - Lachesilla squamiforceps sp. n., male. 26. Fore- and hindwings. 27. Epiproct. 28. Hypandrium, claspers and phallosome apodeme. 29. Right paraproct. Scales in mm. Figures 27-29 to common scale. 
Measurements (of holotype $\hat{\partial}$, those of paratype $\hat{\partial}$ in parenthesis). FW: 2377 (2221), HW: 1772 (1678), F: 481 (490), T: 918 (930), t1:345, t2: 95, ctt1:23, Mx4: 109 (106), f1: 239 (255), IO: 372 (345), D: 203 (221), d: 137 (142), IO/D: 1.83 (1.56), PO: 0.67 (0.64).

Type material. Colombia. Amazonas. Leticia. Sendero Quebrada Tacaná, 100m., 10.XI.1991. E. Flores. Holotype đ̊. Comunidad indígena Monilla Amena, 100m., 12.XI.1991. E. Flores. Paratype ô (ICN).

Etymology. The specific name, a noun in apposition, refers to the field of scales on the claspers of this species.

\section{DISCUSSION}

Lachesilla cuzcoensis keeps a sister group relationship with L. ruizabreorum García Aldrete, known only from Misiones, Argentina, quite distant from the type locality of the former, and incorrectly assigned originally to species group pedicularia (see García Aldrete 2004). The similarity in size and shape of the gonapophyses of both species is remarkable; they differ in wing venation and genital details as follows (see also differential diagnosis of the former): the forewing areola postica in the former is apically rounded, not as slanted and triangular as in the latter; the subgenital plate in $L$. cuzcoensis is not posteriorly concave and the whole sclerite is uniformly pigmented (the pigmented area is anteriorly cleft in L. ruizabreorum), besides, the clunium is not as projected posteriorly over the area of the epiproct in the former, as it is in the latter.

Lachesilla amacayacuensis and L. squamiforceps are close in that they share having a field of scales distally on the surface of the claspers, and both are close to L. pilosiforceps, that presents a field of setae ante-distally on the claspers. The structural plan of the male genitalia in group forcepeta has proven to be quite successful, and the ornamentation of the claspers with scales, setae, spines or small denticles, add to the enormous variation observed in the group: L. asperiforceps García Aldrete, from Mexico, Guatemala and Nicaragua, and several related undescribed species from southern Mexico, present a dense field of microspines on the surface of the claspers; the distal end of the claspers in L. spiniforceps García Aldrete, from the Tambopata Reserved Zone in the Peruvian Amazonia present a field of medium-long spines, and L. yanomami Mockford, from Roraima, Brazil, L. yanomamioides García Aldrete, from Mexico, Guatemala and Trinidad, and L. gracilis García Aldrete, from SE U. S. A., Mexico, Belize and Guatemala, have a row of fine denticles along the inner edge of the distal half of the claspers (García Aldrete 1988, 1996, 2001, 2008; Mockford 1991). The function of these ornaments is unknown, although presumably, they could play a role in mating, or in close distance species recognition.
Lachesilla dilatiforceps García Aldrete (1996) from Puerto Rico and Dominican Republic, and L. pentaoides García Aldrete (2008) from the Tambopata Reserved Zone, together with $L$. marabaensis, constitute a group of related species, having in common stout claspers with mesal projections on the inner side of the distal half; in the three species the claspers are basally rounded, the phallosome apodeme ends in a single membranous area, and the hypandrium is projected posteriorly in the middle in $L$. marabaensis and $L$. pentaoides, and is broadly triangular in $L$. dilatiforceps.

Lachesilla bulbosiforceps and L. pilosipenna share having distinct setae in the pterostigma and forewing veins, including $\mathrm{Cu} 2$ and $\mathrm{A}$, and are the only known species in the group forcepeta to present this character. Setae on forewing veins are extremely rare in species of Lachesilla, this character has only been observed in three species, out of the 283 described in the genus, and in two of the 17 species groups presently recognized in it: the two species of group palmicola (García Aldrete 1981) (L. caecilioides García Aldrete and L. palmicola García Aldrete, both from Mexico), and in one species of group pedicularia (L. hirsuta Lienhard 2002 from Thailand); L. marginata New and Thornton (1975), from Mato Grosso, Brazil, has setae on the forewing margin.

The species here dealt with rise to 97 the number of described species of Lachesilla in continental South America, they rise to 290 the number of described species of Lachesilla in the world, and rise to 93 the number of described species in the group forcepeta. As there are 50 known undescribed species from Bolivia, Ecuador and Peru, all in the Amazon Basin and already represented in my collection, it results that 101 species occur in it, making the Amazon Basin the second most rich area for species of Lachesilla, with seven species groups there represented (andra, forcepeta, fuscipalpis,palmera, pedicularia, riegeli and sclera). The richest area for Lachesilla is Mexico, about 3.5 times smaller than the Amazon Basin, with 164 species and 14 species groups represented (andra,centralis, cerorma, corona, forcepeta, fuscipalpis, magnifica, palmicola, pedicularia, q, riegeli, rufa, sclera and texcocana).

\section{ACKNOWLEDGMENTS}

I am most grateful to Dr. Carlos E. Sarmiento Monroy (Instituto de Ciencias Naturales, Universidad Nacional de Colombia, Bogotá, Colombia), Dr. Diego Carpintero (Museo Argentino de Ciencias Naturales Bernardino Rivadavia, Buenos Aires, Argentina), and Dr. José Albertino Rafael (Instituto Nacional de Pesquisas da Amâzonia, Manaus, Brazil), for making available for study the specimens of the species here described. Felipe Villegas (Instituto de Biología, UNAM), helped importantly with the illustrations. I thank Instituto de Biología, Universidad Nacional Autónoma de México for supporting my research over the years. 


\section{LITERATURE CITED}

García Aldrete, A. N. 1981. The species group palmicola of the genus Lachesilla (Psocoptera: Lachesillidae). Folia Entomológica Mexicana, 47: 25-35. (English).

García Aldrete, A. N. 1988. Species of Lachesilla (Psocoptera: Lachesillidae) from the coast of the Mexican state of Jalisco. Folia Entomológica Mexicana, 77: 33-61. (English).

García Aldrete, A. N. 1996. Species of Lachesilla in the Caribbean islands and Trinidad (Insecta: Psocoptera: Lachesillidae). Insecta Mundi, 10 (1-4): 105-138. (English).

García Aldrete, A. N. 2001. The Lachesillidae (Insecta: Psocoptera) of Nicaragua. Anales del Instituto de Biología, Universidad Nacional Autónoma de México, Serie Zoología, 72(2): 177-197. (English).

García Aldrete, A. N. 2004. Records and descriptions of Lachesilla (Psocoptera: Lachesillidae) from Argentina. Studies on Neotropical Fauna and Environment, 39 (3): 207-215. (English).

García Aldrete, A. N. 2008. Lachesillidae (Insecta: Psocoptera) from the Tambopata Reserved Zone, Madre de Dios, Peru. Publicaciones Especiales del Instituto de Biología, 21. Universidad Nacional Autónoma de México, México, D. F. 92 p. (English).
Lienhard, C. 2002. Three extraordinary new species of Psocoptera (Insecta) from Colombia, Malaysia and Thailand (Epipsocidae, Lachesillidae, Ectopsocidae). Revue Suisse de Zoologie, 109 (2): 383-395. (English).

Mockford, E. L. 1991. New species and records of Psocoptera (Insecta) from Roraima State, Brazil. Acta Amazonica, 21: 211 317. (English).

Mockford, E. L. 1993. North American Psocoptera (Insecta). Flora and Fauna Handbook, 10. Sandhill Crane Press, Gainesville, Florida. 455 pp. (English).

New, T. R.; Thornton, I. W. B. 1975. Psocomorpha (Psocoptera) collected onz recent expeditions to South America. Journal of Entomology (B), 44(1): 27-80. (English).

Recebido em 15/11/2009

Aceito em 13/01/2010 